\title{
Responses of bacterioplankton and phytoplankton to organic carbon and inorganic nutrient additions in contrasting oceanic ecosystems
}

\author{
David A. Caron ${ }^{1, *}$, Ee Lin Lim ${ }^{1,2}$, Robert W. Sanders ${ }^{2}$, Mark R. Dennett ${ }^{3}$, \\ Ulrike-G. Berninger ${ }^{4}$ \\ ${ }^{1}$ Department of Biological Sciences, University of Southern California, 3616 Trousdale Parkway, AHF 301, Los Angeles, \\ California 90089-0371, USA \\ ${ }^{2}$ Temple University, Department of Biology, Philadelphia, Pennsylvania 19122, USA \\ ${ }^{3}$ Department of Biology, Woods Hole Oceanographic Institution, Woods Hole, Massachusetts 02543, USA \\ ${ }^{4}$ Institut für Meereskunde, Abteilung Meeresbotanik, Düsternbrooker Weg 20, 24105 Kiel, Germany
}

\begin{abstract}
Experiments were carried out on Georges Bank, a productive coastal region in the northwestern sector of the North Atlantic Ocean, and in the oligotrophic western Sargasso Sea to examine the effects of nutrient (inorganic nitrogen and phosphorus) and organic carbon (glucose) additions on bacterial and phytoplankton growth. Four experiments were conducted in each environment. Phytoplankton growth was monitored over a $36 \mathrm{~h}$ period by following changes in the concentration of chlorophyll in unfiltered seawater and in seawater prefiltered through $5 \mu$ screening to reduce grazing pressure. Bacterial production was estimated initially and after $24 \mathrm{~h}$ using the ${ }^{3} \mathrm{H}$ thymidine (TdR) method in unfiltered seawater and in $1 \mu \mathrm{m}$ filtrate. Phytoplankton biomass increased significantly in response to nutrient additions in all but 1 experiment, whereas chlorophyll concentrations remained unchanged or decreased in all of the unamended (control) treatments or treatments supplemented with glucose. Responses of the phytoplankton community were similar for the $<5 \mu \mathrm{m}$ and unfiltered treatments. Bacterial production increased after $24 \mathrm{~h}$ in all of the treatments on Georges Bank, and there was little effect of nutrient or glucose addition in unfiltered seawater relative to unamended controls. However, glucose addition to the $<1 \mu \mathrm{m}$ filtrate caused substantial increases in bacterial production relative to controls and N/P-amended treatments in 2 of the experiments from this environment. Glucose had no stimulatory effect (relative to unamended treatments) in 3 of the 4 Sargasso Sea experiments, and only a marginal effect in the fourth. However, the addition of inorganic nitrogen and phosphorus in the latter ecosystem resulted in higher bacterial production (relative to unamended treatments or glucose addition) in 2 of the experiments with unfiltered seawater, and very large increases in 3 of the experiments with $1 \mu \mathrm{m}$ filtrate. The magnitude of the changes in bacterial production differed greatly between unfiltered and filtered seawater in both ecosystems, indicating an important role for bacterial grazers in controlling bacterial population growth. The results of this study indicate different nutritional restraints on bacterial production in these contrasting environments.
\end{abstract}

KEY WORDS: Bacteria · Phytoplankton · Nutrients · Microbial growth • Bacterial production · Georges Bank · Sargasso Sea

Resale or republication not permitted without written consent of the publisher

\section{INTRODUCTION}

Conventional wisdom among plankton biologists has evolved during the past decade regarding the factors that limit primary and bacterial production in the

*E-mail: dcaron@wrigley.usc.edu ocean. For example, the potential for micronutrients (e.g. iron) rather than major nutrients $(N, P)$ to limit rates of phytoplankton production and affect species composition in high nutrient, low production regions of the ocean has been demonstrated experimentally during the past several years (Landry et al. 1997, Cavender-Bares et al. 1999). Similarly, the dogma that bacte- 
rial growth rates are dictated by available organic carbon (energy for growth) has been challenged in recent years, and nitrogen and phosphorus have been recognized as elements whose scarcity might restrain bacterial production in some aquatic ecosystems (Caron 1994, Kirchman 1994, Elser et al. 1995, Rivkin \& Anderson 1997). Fueled by these insights, there is a growing recognition that the factors limiting productivity of bacteria and phytoplankton in the ocean are likely to change over a variety of spatial and temporal scales.

There is justification to believe that bacterial production in nature is limited at times by nitrogen or phosphorus availability. Bacterial biomass is relatively $\mathrm{N}$ and P-rich compared to the gross chemical composition of most other plankton (Vadstein \& Olsen 1989). This situation results in C:N and C:P ratios for bacteria that are generally lower than ratios for phytoplankton. In addition, the cellular stoichiometry of bacteria appears to be less flexible than the carbon:nutrient ratios for some plankton (Caron 1990). These results imply that the overall $\mathrm{C}: \mathrm{N}: \mathrm{P}$ ratio of bacterial substrate(s) in nature must be relatively low in order to meet bacterial N and P demand (Goldman et al. 1987, Goldman \& Dennett 1991). However, this prediction must be tempered by considerations of bacterial growth efficiency because carbon incorporation ultimately dictates nitrogen and phosphorus demand by the growing cells (Coffin et al. 1993, del Giorgio \& Cole 1998).

Numerous studies have now demonstrated inorganic N/P uptake by bacteria and/or growth limitation of these assemblages in a variety of marine and freshwater ecosystems (Cotner \& Wetzel 1992, Zweifel et al. 1993, Kroer et al. 1994, Le et al. 1994, Chrzanowski et al. 1995, Elser et al. 1995, Hoch \& Kirchman 1995, Schweitzer \& Simon 1995, Jansson et al. 1996, Thingstad et al. 1998). Collectively these studies indicate that bacteria acquire a significant fraction of their $\mathrm{N}$ and/or P via the uptake of inorganic forms of these elements. This behavior places bacteria in direct competition with phytoplankton for these growth-limiting nutrients. In support of this observation, laboratory studies have indicated that bacteria can compete effectively with some phytoplankton for inorganic N and $\mathrm{P}$, although the overall applicability and implications of these results for natural plankton communities remain controversial (Currie \& Kalff 1984, Vadstein 1998).

Phytoplankton, for their part, may exacerbate their own nutrient stress as they compete with bacteria for a limiting nutrient. This situation may arise via the release (through either direct excretion or the activities of zooplankton) of carbon-rich, nutrient-poor organic materials which may be stored by algal cells in the absence of sufficient $\mathrm{N}$ or $\mathrm{P}$ for growth. Utilization of these $\mathrm{N}$ - or P-deficient materials as substrate by the bacteria may increase their uptake of dissolved inorganic $\mathrm{N}$ and $\mathrm{P}$. The apparent paradox of this situation (bacteria outcompeting the phytoplankton which are their ultimate source of organic substrate) has been recognized, as have been possible solutions to this paradox (Bratbak \& Thingstad 1985). These solutions include a reduction in bacterial substrate (organic carbon) supply as phytoplankton become outcompeted from the ecosystem, or removal and remineralization of bacterial biomass by bacterivorous protists.

The generality emerging from these laboratory and field observations is that a bacterial population may experience strong $\mathrm{N}$ or $\mathrm{P}$ limitation when the phytoplankton are also nutrient-limited. Conversely, when inorganic nutrients are abundant, $\mathrm{N}$ and $\mathrm{P}$ in nutrientrich organic material produced and released by the phytoplankton assemblage may meet the $\mathrm{N}$ and $\mathrm{P}$ requirements of the bacteria, precluding the need for the uptake of inorganic nutrients by heterotrophic prokaryotes. If true, these contrasting scenarios should be demonstrable in pelagic ecosystems that differ in their degree of nutrient availability.

We tested this hypothesis in experimental studies conducted on Georges Bank and in the western Sargasso Sea in the North Atlantic to examine the effect of nutrient and carbon additions on bacterial growth. Our goal was to compare the response of the bacteria at these different locations to additions of major nutrients (inorganic nitrogen and phosphorus) and organic carbon (glucose) additions. In addition, we monitored the effect that these amendments had on the phytoplankton community. Overall, nutrient additions (but not organic carbon) stimulated phytoplankton growth in both environments in all but 1 of 8 experiments. Bacterial production, however, was affected more strongly on Georges Bank by additions of organic carbon (2 out of 4 experiments) while nutrient additions consistently stimulated bacterial growth in the Sargasso Sea.

\section{METHODS AND MATERIALS}

Georges Bank is a shallow, productive coastal environment in the northwestern sector of the North Atlantic. It is characterized by anticyclonic circulation and strong tidal mixing that results in complete vertical mixing on portions of the bank and high rates of primary and secondary production (Wiebe \& Beardsley 1996). In contrast, the western Sargasso Sea is a highly oligotrophic, oceanic gyre ecosystem characterized by a deep permanent thermocline and a strong seasonal thermocline (Michaels \& Knap 1996).

Locations were chosen on the northern edge of Georges Bank (approximately $42^{\circ} 00^{\prime} \mathrm{N}, 67^{\circ} 40^{\prime} \mathrm{W}$ ) and 
in the western Sargasso Sea south of Bermuda (approximately $31^{\circ} 42^{\prime} \mathrm{N}, 64^{\circ} 10^{\prime} \mathrm{W}$ ) during the summer of 1991. Experiments were conducted on 4 dates at 2 to $4 \mathrm{~d}$ intervals at each station. No attempt was made to follow a discrete water parcel during this period. The ship returned to the same general coordinates at the time of sampling. Water samples were collected at $2 \mathrm{~m}$ on Georges Bank and at $15 \mathrm{~m}$ in the Sargasso Sea. At all stations, water was collected in acid-cleaned $30 \mathrm{l}$ Niskin bottles fitted with Teflon-coated springs and o-rings in conjunction with CTD casts for profiles of water column temperature and in situ fluorescence.

Subsamples were gently filtered (<30 mm Hg) through $1 \mu \mathrm{m}$ polycarbonate filters to reduce the abundance of bacterivorous organisms, and through $5 \mu \mathrm{m}$ Nitex $^{\circledR}$ screening to reduce the number of herbivorous organisms. This filtration acted to reduce chlorophyll concentration by up to $\sim 50 \%$ for the Georges Bank samples. Chlorophyll values in the Sargasso Sea samples were virtually unchanged in the filtrate, in agreement with previous studies that have indicated the dominance of small algae in the latter ecosystem (Li et al. 1992, Caron et al. 1995). Filtrate was prepared for experiments on all dates except 31 July. Three treatments were then prepared with filtered and unfiltered seawater: (1) treatments supplemented with inorganic nitrogen and phosphorus received $10 \mu \mathrm{M} \mathrm{N}$ as ammonium $\left(\mathrm{NH}_{4} \mathrm{Cl}\right)$ and $1 \mu \mathrm{M}$ P as phosphate $\left(\mathrm{Na}_{2} \mathrm{HPO}_{4} \cdot 7 \mathrm{H}_{2} \mathrm{O}\right)$; (2) treatments supplemented with organic carbon received $10 \mu \mathrm{M} \mathrm{C}$ as glucose; and (3) treatments with no supplementation (controls).Volumes of $1 \mathrm{l}$ were then placed in $1.25 \mathrm{l}$ polycarbonate bottles (in duplicate). Samples were incubated at ambient water temperature in an on-deck incubator with 1 layer of neutral-density plastic window screening to reduce the light intensity to approximately $50 \%$ of incident intensity.

All treatments were sampled initially (at the time of supplementation), and following 24 and $36 \mathrm{~h}$ of incubation. Changes in phytoplankton biomass were estimated from changes in the concentration of chlorophyll a collected on Whatman GF/F glass fiber filters, and measured fluorometrically (Parsons et al. 1984) using a Turner Designs 110 fluorometer. Particulate organic carbon and nitrogen content were determined from 11 samples collected on precombusted Whatman GF/F glass fiber filters at the completion of the incubation period and frozen until analyzed on a PerkinElmer 240C elemental analyzer. Bacterial production was estimated based on ${ }^{3} \mathrm{H}$-thymidine (TdR) incorporation into DNA modified from protocols of Fuhrman \& Azam (1982). Conversion factors for TdR incorporation were $4.7 \times 10^{18}$ and $3.0 \times 10^{18}$ bacterial cells $\mathrm{mol}^{-1} \mathrm{TdR}$ for Georges Bank and the Sargasso Sea, respectively (Sanders et al. 2000). Bacterial cell carbon content was assumed to be $10 \mathrm{fg} \mathrm{C}^{\mathrm{C}} \mathrm{cell}^{-1}$ based on the small size of cells in natural planktonic assemblages (Nagata 1986). The effects of nutrient/carbon additions on bacterial productivity were examined using an unpaired $t$-test.

Samples collected for estimates of microbial abundance were preserved with glutaraldehyde (1\% final concentration) immediately after collection and prepared within $24 \mathrm{~h}$ for epifluorescence microscopy by staining with 5 to $25 \mu \mathrm{g}$ DAPI ml ${ }^{-1}$ (Porter \& Feig 1980). Bacterial abundances were determined from samples collected on $0.22 \mu \mathrm{m}$ blackened polycarbonate filters. Abundances of nanoplanktonic protists were counted on separate DAPI-stained samples prepared in the same manner. Phototrophic nanoplankton and heterotrophic nanoplankton were differentiated by the presence/absence of chlorophyll autofluorescence using separate filter sets for chlorophyll or DAPI fluorescence (for chlorophyll, BP450-490 excitation filter, FT510 chromatic beam splitter, LP520 barrier filter; for DAPI, G365 excitation filter, FT420 chromatic beam splitter, LP418 barrier filter). At least 60 and usually > 200 nanoplanktonic cells were counted per sample. Variability associated with the microbial population estimates ( 10\% for bacteria and $15 \%$ for nanoplankton) was a consequence of the counting error inherent in the microscopical technique.

\section{RESULTS}

Water column structure, chemical parameters and abundances of microbial assemblages at the 2 sampling locales reflected differences in the trophic state of these 2 environments (Table 1). Ranges for the abundance of bacteria and phototrophic picoplankton (0.2 to $2.0 \mu \mathrm{m}$ phototrophs, primarily chroococcoid cyanobacteria) in the mixed surface layer were 1.0 to $1.3 \times 10^{9} \mathrm{l}^{-1}$ and 3.3 to $69.0 \times 10^{6} \mathrm{l}^{-1}$, respectively, on Georges Bank. Ranges in the abundances of these assemblages for samples from the Sargasso Sea were 0.20 to $0.52 \times 10^{9} \mathrm{l}^{-1}$ for bacteria and 4.1 to $7.8 \times 10^{6} \mathrm{l}^{-1}$ for phototrophic picoplankton. Differences in the abundance of phototrophic nanoplankton (2 to $20 \mu \mathrm{m}$ phototrophs) and chlorophyll were great between the 2 sites. PNAN averaged an order of magnitude more abundant at the Georges Bank site compared to the Sargasso Sea (average $=4.62$ vs $0.34 \times 10^{6} \mathrm{l}^{-1}$ ), and average chlorophyll concentration was approximately 70 -fold higher on Georges Bank (0.98 vs $0.014 \mu \mathrm{g} \mathrm{l}^{-1}$ ).

Particulate organic carbon (POC) in the Georges Bank samples ranged from 245 to $302 \mu \mathrm{g} \mathrm{C}{ }^{-1}$ and particulate organic nitrogen (PON) ranged from 40 to $58 \mathrm{~g} \mathrm{~N} \mathrm{~N}^{-1}$ (Table 1). The molar ratio of POC:PON varied between 5.95 and 7.47 and averaged 6.45 for the 4 experiments. POC concentration in the Sargasso Sea samples averaged about $8.5 \times$ less than that observed 
Table 1. Experimental dates and microbial abundance and biomass estimates from surface samples collected from Georges Bank $(2 \mathrm{~m})$ and the Sargasso Sea $(15 \mathrm{~m})$. PPIC = photosynthetic picoplankton; PNAN = photosynthetic nanoplankton; POC $=$ particulate organic carbon; PON = particulate organic nitrogen

\begin{tabular}{|c|c|c|c|c|c|c|c|c|c|c|}
\hline Stn & $\begin{array}{l}\text { Date } \\
(1991)\end{array}$ & $\begin{array}{l}\text { Depth } \\
\text { (m) }\end{array}$ & $\begin{array}{l}\text { Temp } \\
\left({ }^{\circ} \mathrm{C}\right)\end{array}$ & $\begin{array}{l}\text { Bacteria } \\
\left(10^{9} \mathrm{l}^{-1}\right)\end{array}$ & $\begin{array}{c}\text { PPIC } \\
\left(10^{6} 1^{-1}\right)\end{array}$ & $\begin{array}{c}\text { PNAN } \\
\left(10^{6} 1^{-1}\right)\end{array}$ & $\begin{array}{c}\text { POC } \\
\left(\mu \mathrm{g} \mathrm{l}^{-1}\right)\end{array}$ & $\begin{array}{c}\text { PON } \\
\left(\mu \mathrm{g} \mathrm{l}^{-1}\right)\end{array}$ & $\begin{array}{c}\text { C:N ratio } \\
\text { (mol) }\end{array}$ & $\begin{array}{c}\text { Chlorophyll } \\
\left(\mu \mathrm{g} \mathrm{l}^{-1}\right)\end{array}$ \\
\hline \multicolumn{11}{|c|}{ Georges Bank } \\
\hline 1 & $31 \mathrm{Jul}$ & 2 & 15.8 & 1.30 & 69.0 & 5.28 & 256 & 40 & 7.5 & 1.40 \\
\hline 2 & 2 Aug & 2 & 15.5 & 1.22 & 4.3 & 5.32 & 227 & 42 & 6.3 & 0.48 \\
\hline 3 & 4 Aug & 2 & 16.0 & 1.07 & 3.7 & 5.95 & 302 & 58 & 6.1 & 1.03 \\
\hline 4 & 6 Aug & 2 & 15.6 & 1.00 & 3.3 & 1.94 & 245 & 48 & 6.0 & 1.04 \\
\hline \multicolumn{11}{|c|}{ Sargasso Sea } \\
\hline 5 & $10 \mathrm{Aug}$ & 15 & 28.6 & 0.20 & 7.8 & 0.47 & 48 & 10.2 & 5.5 & 0.017 \\
\hline 6 & $14 \mathrm{Aug}$ & 15 & 28.9 & 0.30 & 4.1 & 0.46 & 21 & 5.3 & 4.7 & 0.012 \\
\hline 7 & 16 Aug & 15 & 28.6 & 0.26 & 5.1 & 0.28 & 24 & 7.5 & 3.7 & 0.014 \\
\hline 8 & 19 Aug & 15 & 28.6 & 0.52 & 4.9 & 0.17 & 28 & 4.5 & 7.2 & 0.014 \\
\hline
\end{tabular}

on Georges Bank, while PON was reduced by a factor of about 5.5. POC varied between 21 to $48 \mu \mathrm{g} \mathrm{C}^{-1}$ and

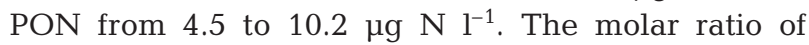
POC:PON ranged from 3.73 to 7.47 and averaged 5.3 for the 4 experiments in the Sargasso.

\section{Georges Bank experiments}

Supplementation of whole, unfiltered seawater with inorganic nitrogen and phosphorus resulted in sub- stantial increases in chlorophyll concentration in all 4 experiments performed in this coastal sea (average increase of 2.5-fold; Fig. 1A-D). In contrast, bottles that had additions of glucose or no supplementation (controls) showed significant decreases $(p<0.05)$ in chlorophyll over the duration of the $36 \mathrm{~h}$ experiments in 3 of the 4 experiments with unfiltered seawater. Chlorophyll changes in the $<5 \mu \mathrm{m}$ filtrate during the experiments on Georges Bank were similar to changes observed in unfiltered seawater in both their general trends and magnitudes (Fig. 1E-G).
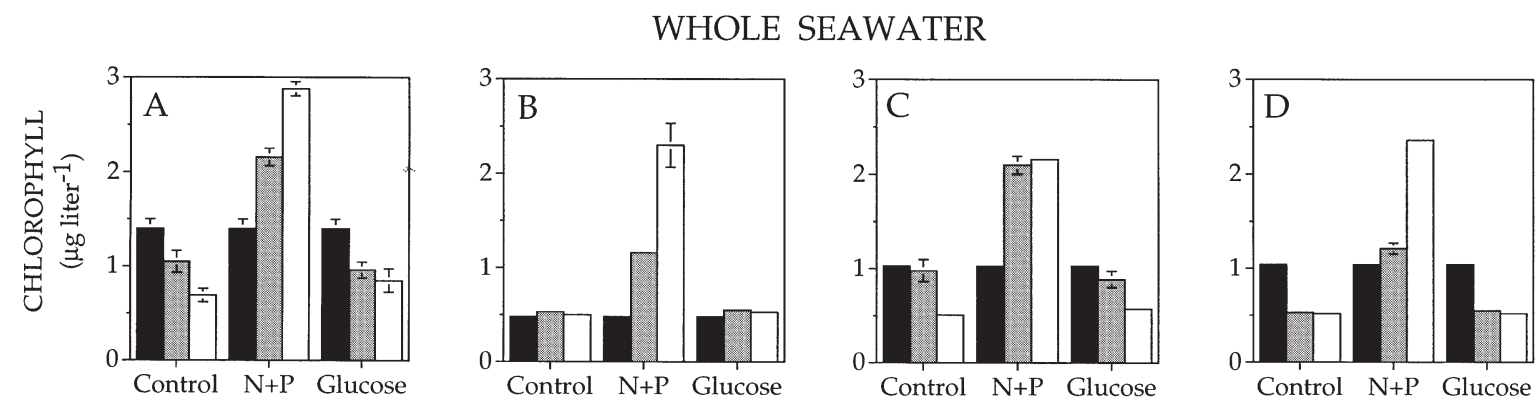

\section{$<5 \mu \mathrm{m}$ FRACTION}
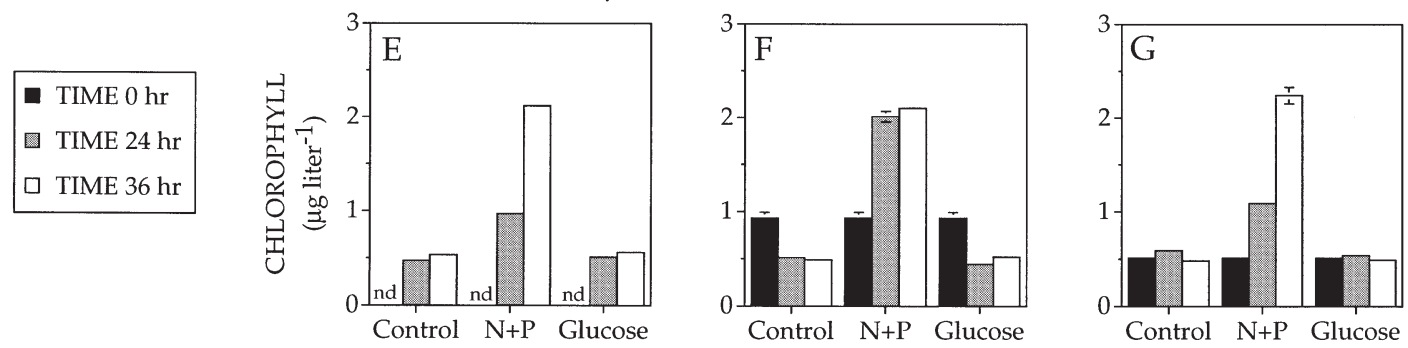

Fig. 1. Changes in chlorophyll concentration ( $\mu \mathrm{g} \mathrm{l} \mathrm{l}^{-1}$ ) during $36 \mathrm{~h}$ incubations in (A-D) whole (unfiltered) seawater samples or (E-G) $5 \mu \mathrm{m}$ filtrate. Water was collected on Georges Bank on (A) 31 July, (B,E) 2 August, (C,F) 4 August and (D, G) 6 August. Samples received no nutrient or organic supplementation (Control), or they were supplemented with inorganic nitrogen and phosphorus $(\mathrm{N}+\mathrm{P})$ or glucose (Glucose). No experiment was performed with filtrate on 31 July. Error bars indicate \pm 1 SD. Error bars are too small to be visible for some treatments 

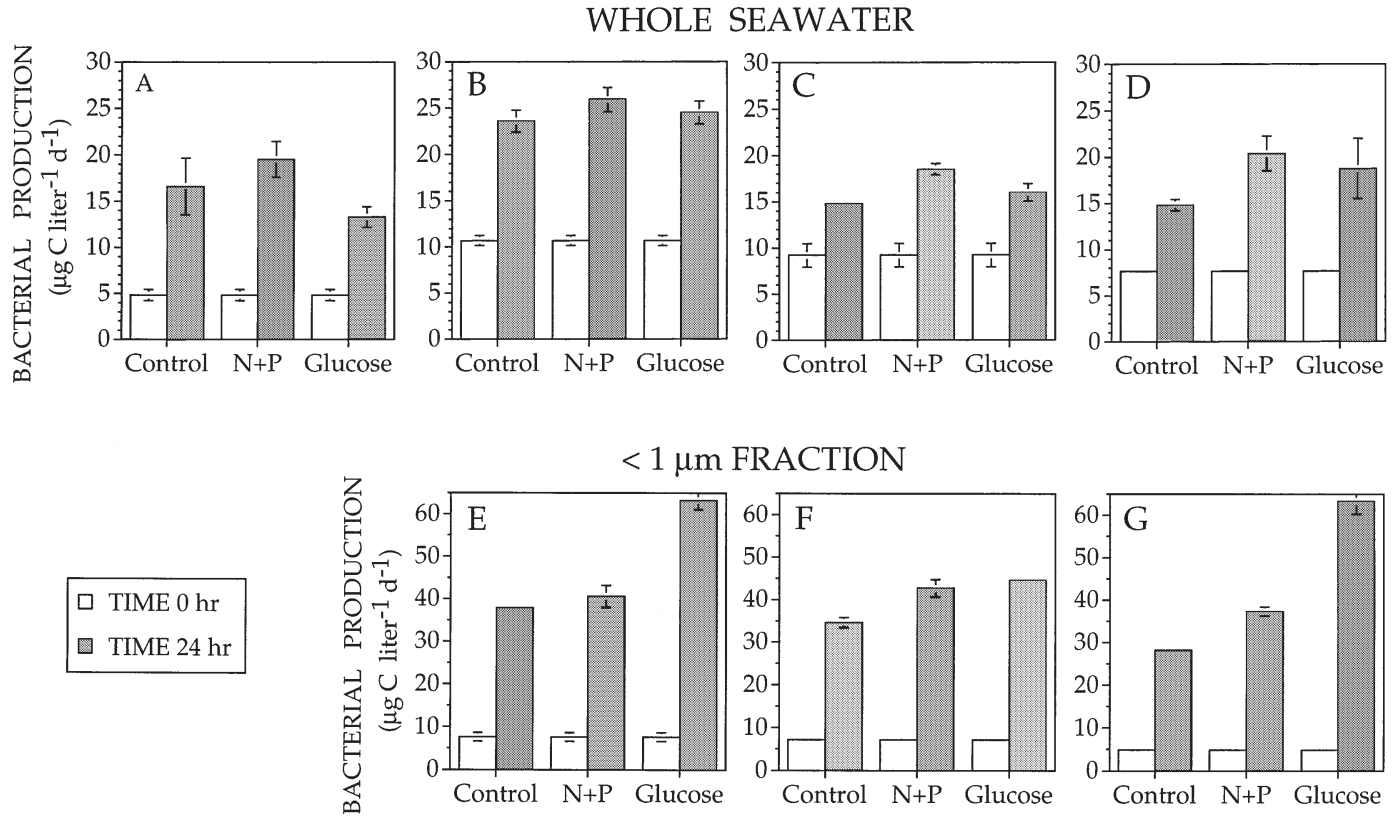

Fig. 2. Changes in bacterial production $\left(\mu \mathrm{g} \mathrm{C} \mathrm{l}^{-1} \mathrm{~d}^{-1}\right)$ during $24 \mathrm{~h}$ incubations in (A-D) whole (unfiltered) seawater samples or (E-G) $1 \mu \mathrm{m}$ filtrate. Water was collected on Georges Bank on (A) 31 July, (B,E) 2 August, (C,F) 4 August and (D, G) 6 August. Samples received no nutrient or organic supplementation (Control), or they were supplemented with inorganic nitrogen and phosphorus (N+P) or glucose (Glucose). No experiment was performed with filtrate on 31 July. Error bars indicate \pm 1 SD. Error bars are too small to be visible for some treatments

Rates of bacterial production at the beginning of the experiments on Georges Bank ranged from approximately 4.5 to $11 \mu \mathrm{g} \mathrm{C}^{-1} \mathrm{~d}^{-1}$ (Fig. 2). These values were significantly greater $(\mathrm{p}<0.05)$ in all experimental treatments after $24 \mathrm{~h}$ compared to initial measurements. Bacterial production in the control treatments of the whole (unfiltered) seawater samples after $24 \mathrm{~h}$ of incubation averaged twice the initial values (Fig. 2A-D). Unfiltered seawater supplemented with inorganic nutrients had production rates at $24 \mathrm{~h}$ that differed from control treatments in 1 experiment (4 August; Fig. 2C), but this treatment did not differ significantly $(p<0.05)$ from production rates in samples supplemented with glucose. Glucose enrichment did not result in significant increases in bacterial productions (relative to controls) in any of the experiments with unfiltered seawater.

Bacterial production was measured in the $1 \mu \mathrm{m}$ filtrate for 3 experiments performed on Georges Bank in an effort to examine bacterial growth under conditions of reduced predation. Initial bacterial production values in these filtrates were similar or less than production values in the unfiltered samples (one filtrate had a significantly lower production than the corresponding value in the unfiltered seawater; $\mathrm{p}<0.05)$, which presumably indicated that most of the bacterial assemblage passed through the $1 \mu \mathrm{m}$ filters. Production values after $24 \mathrm{~h}$ of incubation in the $1 \mu \mathrm{m}$ filtrates, however, were greatly increased relative to increases observed in the unfiltered samples. TdR values in the $<1 \mu \mathrm{m}$ control treatments at $24 \mathrm{~h}$ averaged $3.7 \times$ the values for the same samples at the beginning of the incubations.

Bacterial production in the $\mathrm{N}+\mathrm{P}$ treatments with $1 \mu \mathrm{m}$ filtrate was significantly greater $(\mathrm{p}<0.05)$ than production in the control treatments in 2 of the 3 experiments (Fig. 2F, G). Production in the glucose treatments, however, was significantly greater than production in controls in all 3 experiments (Fig. 2E-G; $\mathrm{p}<$ 0.05 ) and greater than the $\mathrm{N}+\mathrm{P}$ treatments in 2 of the experiments (Fig. 2E, Gi p < 0.05). In the latter 2 experiments ( 2 and 6 August), glucose increased bacterial production 56 and $62 \%$ relative to $\mathrm{N}+\mathrm{P}$ additions, respectively, and 66 and $120 \%$ relative to production in the controls treatments.

\section{Sargasso Sea experiments}

The pattern of changes in chlorophyll in the 4 experiments performed in the Sargasso Sea were comparable to results on Georges Bank with the exception of the 16 August experiment (Fig. 3). The control and glucose treatments using unfiltered Sargasso Sea water showed no significant increases $(\mathrm{p}<0.05)$ in chlorophyll during the $36 \mathrm{~h}$ incubations. In 1 experiment, chlorophyll in these 2 treatments decreased during the incubation period (16 August; Fig. 3C). In contrast to 
WHOLE SEAWATER
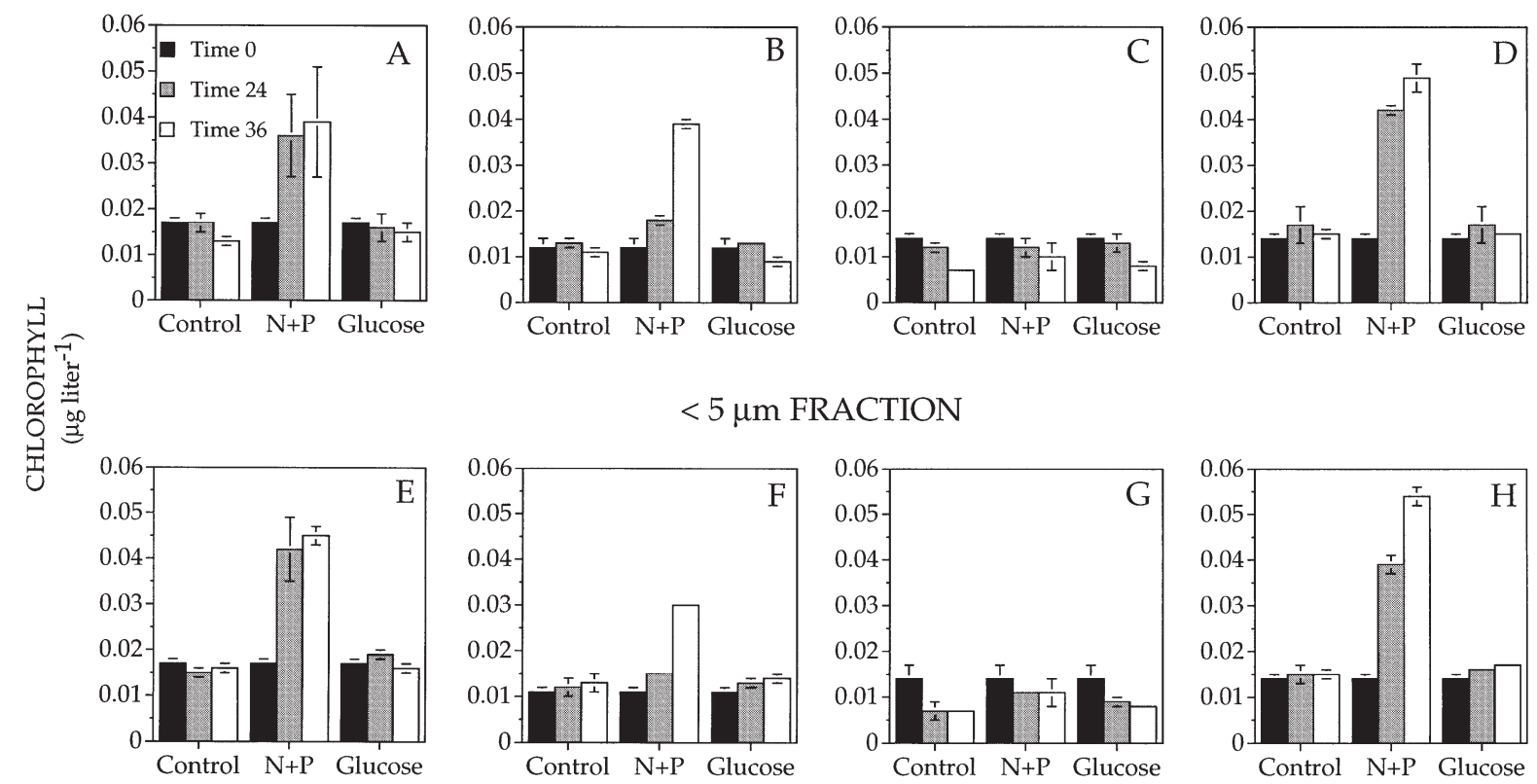

\section{$<5 \mu \mathrm{m}$ FRACTION}
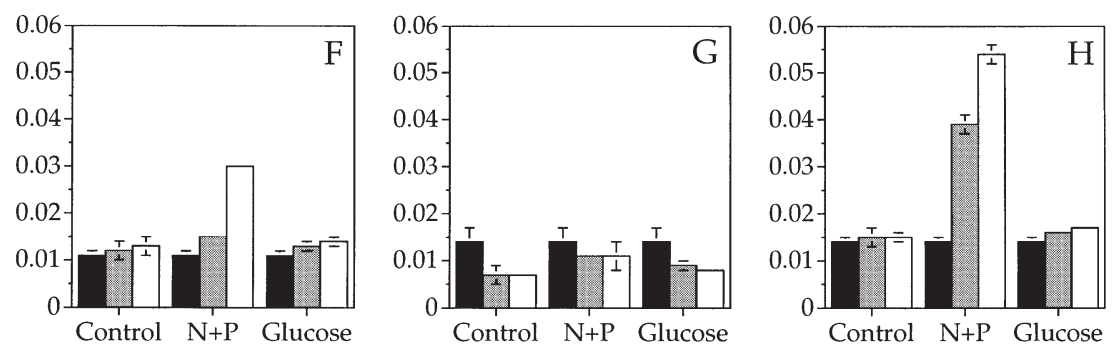

Fig. 3. Changes in chlorophyll concentration ( $\mu \mathrm{g} \mathrm{l^{-1 }}$ ) during $36 \mathrm{~h}$ incubations in (A-D) whole (unfiltered) seawater samples or (E-H) $5 \mu \mathrm{m}$ filtrate. Water was collected in the Sargasso Sea on (A, E) 10 August, (B,F) 14 August, (C, G) 16 August and (D,H) 19 August. Samples received no nutrient or organic supplementation (Control), or they were supplemented with inorganic nitrogen and phosphorus $(\mathrm{N}+\mathrm{P})$ or glucose (Glucose). Error bars indicate $\pm 1 \mathrm{SD}$. Error bars are too small to be visible for some treatments

the controls and glucose amended treatments, chlorophyll increased markedly (average of 3-fold) in treatments amended with $\mathrm{N}+\mathrm{P}$ in 3 of the experiments (Fig. 3A, B, D). Changes in the $<5 \mu \mathrm{m}$ fraction were similar in pattern and magnitude to changes in the unfiltered seawater in all 4 experiments (Fig. 3E-H). Chlorophyll did not increase in any of the treatments on 16 August in the Sargasso Sea (Fig. 3C, G). Presumably, this result indicated that some other factor was limiting growth of the phytoplankton assemblage at that time and place.

The responses of the bacterial assemblages in the Sargasso Sea to nutrient or carbon supplementation were quite different from those obtained on Georges Bank (Fig. 4). Initial bacterial production in the Sargasso Sea was much lower than values obtained on Georges Bank (range $\approx 0.3$ to $1.1 \mu \mathrm{g} \mathrm{Cl}^{-1} \mathrm{~d}^{-1}$ for unfiltered seawater samples). Glucose additions to whole, unfiltered seawater did not increase bacterial production relative to controls for any of the 4 experiments in the Sargasso Sea. Bacterial production following N+P additions on 10 and 16 August, however, showed significantly elevated bacterial productivity relative to the control or glucose treatments (Fig. 4A, $C_{i} p<0.05$ ).

Bacterial production in the $1 \mu \mathrm{m}$ filtrates in the Sargasso Sea responded dramatically to inorganic nitrogen and phosphorus supplementation in 3 of the 4 experiments (Fig. 4F-H; 14, 16 and 19 August). A minor (but significant; $\mathrm{p}<0.05$ ) response also was obtained on 10 August (Fig. 4E). Bacterial production showed a significant response to glucose additions in only 1 of the experiments (10 August), and this value was not significantly different than the response elicited by the $\mathrm{N}+\mathrm{P}$ treatment in that experiment (Fig. 4E).

\section{DISCUSSION}

\section{Phytoplankton growth limitation}

Phytoplankton growth responded positively to inorganic nutrient enrichment in 7 of the 8 experiments performed in this study. This result is not surprising given the environments sampled and the season. The Sargasso Sea south of Bermuda is a highly oligotrophic ecosystem characterized by low nutrient availability in summer (Michaels \& Knap 1996). A strong seasonal thermocline was present during August. A weak but persistent thermocline also was present at the Georges Bank station near the northern edge of the bank (Sanders et al. 2000). Phytoplankton under these conditions might be expected to experience some level of nutrient limitation.

Net growth rates of the phytoplankton assemblage were estimated for these experiments by assuming that the amount of chlorophyll cell ${ }^{-1}$ remained constant 

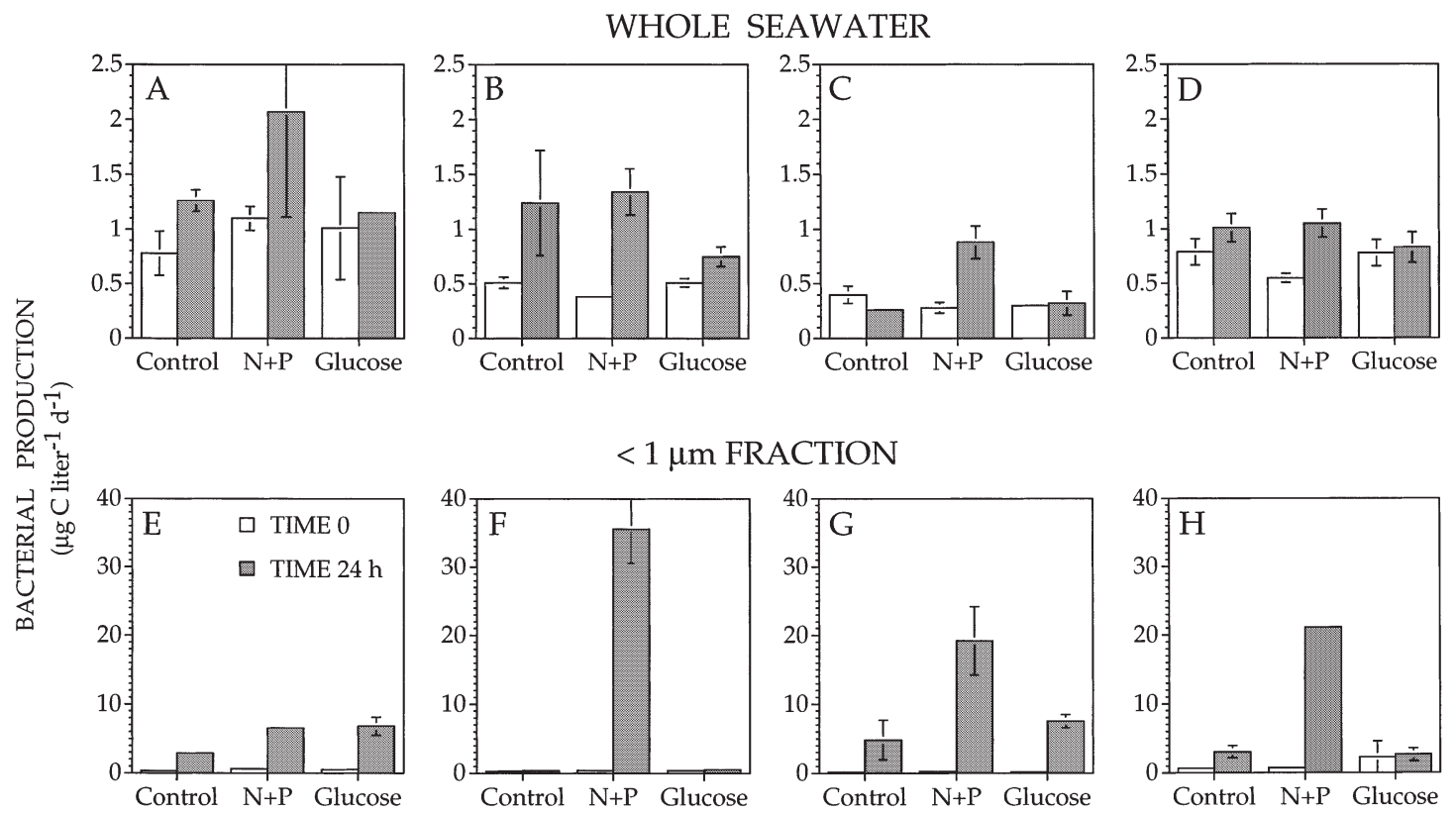

Fig. 4. Changes in bacterial production $\left(\mu \mathrm{g} \mathrm{C} \mathrm{l}^{-1} \mathrm{~d}^{-1}\right.$ ) during $24 \mathrm{~h}$ incubations in (A-D) whole (unfiltered) seawater samples or (E-H) $1 \mu \mathrm{m}$ filtrate. Water was collected in the Sargasso Sea on (A,E) 10 August, (B, F) 14 August, (C, G) 16 August and (D, H) 19 August. Samples received no nutrient or organic supplementation (Control), or they were supplemented with inorganic nitrogen and phosphorus $(\mathrm{N}+\mathrm{P})$ or glucose (Glucose). Error bars indicate $\pm 1 \mathrm{SD}$. Error bars are too small to be visible for some treatments

throughout the incubation, and that algal growth was exponential during the $36 \mathrm{~h}$ incubations. Net growth rates determined in this manner in the unfiltered seawater samples amended with $\mathrm{N}+\mathrm{P}$ ranged from 0.48 to $1.04 \mathrm{~d}^{-1}$ on Georges Bank, and -0.22 to $0.84 \mathrm{~d}^{-1}$ in the Sargasso Sea. Excluding the one experiment in the Sargasso Sea where the community did not respond positively to nitrogen and phosphorus enrichment, the overall average for both environments was $0.68 \mathrm{~d}^{-1}$. These values are in contrast to net growth rates of the phytoplankton assemblages in the control treatments and in the glucose treatments. On Georges Bank, phytoplankton net growth rates in the control and glucose treatments were estimated to be $-0.45 \mathrm{~d}^{-1}$ and $-0.27 \mathrm{~d}^{-1}$, respectively. The corresponding average rates estimated for the Sargasso Sea samples were $-0.06 \mathrm{~d}^{-1}$ and $-0.07 \mathrm{~d}^{-1}$ excluding the experiment where none of the treatments produced positive net growth rates (16 August; Fig. 3C). Phytoplankton growth therefore appeared to be quite constrained in the control treatments relative to the nutrient-enriched treatments.

These rates should not be taken as accurate estimates of phytoplankton growth rates, but rather as a useful way of comparing relative growth rates in the various treatments. They were calculated by assuming that there was no photoadaptation of the algae during the incubations (constant chlorophyll cell ${ }^{-1}$ ). However, changes in chlorophyll content may have occurred in some (or all) of the treatments as a consequence of photoadaptation to light conditions in the on-deck incubations, or to changes in nutritional status. Such changes would make our estimates of absolute phytoplankton growth rates inaccurate.

We expected that the addition of a labile, nutrientfree carbon source for the bacteria (glucose) might stimulate bacterial competition for dissolved inorganic nutrients and thus lower phytoplankton growth rates. Phytoplankton growth rates in the unamended treatments apparently were already quite low (see paragraph above), and thus the addition of glucose did not lead consistently to decreases in these rates in excess of the decreases observed in the controls.

The responses of the phytoplankton assemblages to inorganic nutrient additions were similar in the unfiltered seawater samples and the $<5 \mu \mathrm{m}$ filtrates. These filtrates were prepared with the expectation that phytoplankton in the filtrate might experience lower grazing pressure in the absence of herbivores $>5 \mu \mathrm{m}$. Our findings indicate that either grazing pressure was low on the phytoplankton assemblage responding to nutrient additions in the bottles (resulting in similar net growth rates in whole and filtered seawater), or that filtration through $5 \mu \mathrm{m}$ screening did not remove most of the herbivore community (resulting in similar grazing pressures in the filtered and unfiltered seawater). 
Picoplankton biomass has been shown to dominate the phytoplankton biomass of the Sargasso Sea (Olson et al. 1990a, b, Li et al. 1992, Malone et al. 1992), and small nanozooplankton appear to be the major consumers of this biomass (Caron et al. 1999). Therefore, it seems possible that a considerable portion of the herbivore assemblage passed through the $5 \mu \mathrm{m}$ screen.

\section{Bacterial growth limitation}

Nutrient (nitrogen, phosphorus) limitation of phytoplankton growth in a stratified water column is not a unique finding. Demonstration of a positive response of bacterial growth to inorganic nutrient additions in these environments, however, is much less common. The ability of bacteria to take up inorganic nutrients at low concentrations has been known for quite some time, and the ecological significance of this behavior has been recognized and incorporated into some models of nutrient and carbon flow in aquatic ecosystems (Bratbak \& Thingstad 1985, Thingstad 1987). However, empirical evidence for nutrient limitation of bacterial growth in oceanic waters is still rare (Cotner et al. 1997, Rivkin \& Anderson 1997, Shiah 1999). Limitation of bacterial growth by nitrogen or phosphorus presumably occurs as a consequence of the utilization of substrates that have high C:N or C:P values and thus insufficient organic nitrogen or phosphorus for growth (Goldman et al. 1987, Goldman \& Dennett 1991). It has been suggested that labile organic carbon compounds may accumulate under these conditions in the pool of dissolved organic carbon, and that these carbon sources are taken up rapidly and metabolized when the growth-limiting element becomes available (Cotner et al. 1997).

Competition between bacteria and phytoplankton for a growth-limiting nutrient would be expected to intensify as nutrient limitation becomes more severe. For this reason, one might expect highly nutrient impoverished environments to have bacterial assemblages that are often limited by the availability of nitrogen or phosphorus, while less nutrient-stressed communities might be characterized by bacterial assemblages limited by the availability of organic carbon. The results of several of the experiments performed in this study, particularly in the $1 \mu \mathrm{m}$ filtrates, appear to lend support to our speculation. Two of the $1 \mu \mathrm{m}$ filtrates in the experiments on Georges Bank had increased bacterial productivities in response to glucose additions that were far in excess of the responses in the controls or the N+P amended treatments (Fig. 2E,G). In contrast, 3 of the $1 \mu \mathrm{m}$ filtrates in the experiments in the Sargasso Sea had large increases in bacterial production within $24 \mathrm{~h}$ of inorganic nitrogen and phosphorus additions
(Fig. 4F-H). These same bacterial assemblages showed no response to glucose additions (relative to control treatments). The response of the assemblages to nitrogen and phosphorus additions but not glucose in these latter experiments implies a strong limitation of bacterial growth by one of the former elements.

Two recent studies in the Sargasso Sea have detected phosphorus limitation of bacterial growth (Cotner et al. 1997, Rivkin \& Anderson 1997). Our findings are consistent with those reports, although our experiments did not differentiate nitrogen from phosphorus limitation. The initial particulate $\mathrm{C}: \mathrm{N}$ ratios in all of our Sargasso Sea experiments were approximately equal to or less than the Redfield ratio of 6.6 (Table 1). This result may indicate that nitrogen was not limiting during our study in the Sargasso Sea (Goldman et al. 1979). The magnitude of the bacterial response when nitrogen and phosphorus were added to our incubations apparently indicates the presence of a substantial pool of labile organic carbon which may be utilized when these inorganic nutrients become available (Cotner et al. 1997).

Bacterial production after $24 \mathrm{~h}$ of incubation was much higher in all $1 \mu \mathrm{m}$ filtrates than production in the unfiltered seawater samples for both the Georges Bank and Sargasso Sea experiments (note different ranges for bacterial production values in Fig. 2B-D compared to $2 \mathrm{E}-\mathrm{F}$, and in Fig. $4 \mathrm{~A}-\mathrm{D}$ compared to $4 \mathrm{E}-\mathrm{H}$ ). This finding is interesting in view of the fact that filtration might be expected to have 3 major effects on bacterial production in the filtrates; removal of the source of organic carbon and nutrients arising from production and grazing by organisms $>1 \mu \mathrm{m}$, enhanced substrate/nutrient supply due to the physical disruption of delicate plankton by the filtration process, and reduced grazing impact on the bacterial assemblage because of the removal of bacterivores $>1 \mu \mathrm{m}$.

The first of these possibilities appears not to have been an important issue during the $24 \mathrm{~h}$ incubation period as evidenced by the greater production observed in all filtrates relative to unfiltered water samples. The opposite result might have been expected if bacterial growth was tightly coupled to the release of materials by larger phytoplankton and consumers. On the other hand, it is possible that filtration caused damage to delicate plankton which resulted in the release of substantial amounts of labile organic material and/or nutrients to the filtrates. Clearly, substrate was available in the unamended filtrates as evidenced by the increased bacterial production observed in the filtrates after $24 \mathrm{~h}$ (Figs. 2E-F \& 4E-G). However, it is unclear if this substrate was the result of filtration or if it was naturally present in the sample at the time of filtration.

Alternatively, increased bacterial production observed in the filtrates may indicate that bacterial bio- 
mass was removed rapidly by predation in the unfiltered samples, but not in the $1 \mu \mathrm{m}$ filtrates, for both the coastal and oceanic sites. Bacterial production is a product of bacterial growth rates and bacterial standing stocks. If bacteria were growing at the same rate in the filtrates and the unfiltered seawater samples, but were removed rapidly by predators in the unfiltered samples during the $24 \mathrm{~h}$ incubations, then bacterial production in the filtrates at $24 \mathrm{~h}$ would reflect the higher standing stocks of bacteria. Thus, the elevated differences in the bacterial production at $24 \mathrm{~h}$ between filtrates and unfiltered samples could reflect different predation pressures between these 2 treatments rather than differences in the availability of substrate and/or nutrients as an artifact of filtration. That is, the response of bacterial production to carbon/nutrient additions may simply have been more dramatic in the filtrates as a consequence of reduced rates of bacterivory in those treatments.

The latter scenario is consistent with the results of studies of bacterivory in these environments which indicated that bacterial production was in approximate balance with microbial predation (Caron et al. 1999, Sanders et al. 2000). If this interpretation is generally true, then it would support the idea that the uptake of inorganic nutrients by the bacteria is a substantial sink of inorganic $\mathrm{N}$ and $\mathrm{P}$ in these ecosystems, that this uptake is balanced by ingestion and digestion of bacterial biomass, and that remineralization of bacterial biomass may constitute an important source of nutrients for phytoplankton.

Bacterial production on Georges Bank after $24 \mathrm{~h}$ of incubation was greater than initial production values even for bottles that received no nutrients or organic carbon (Fig. 2). This result was also observed for some of the experiments in the Sargasso Sea (Fig. 4). This effect was not attributable solely to a filtration artifact because it was apparent in the unfiltered seawater samples as well as in the $1 \mu \mathrm{m}$ filtrates. These consistent increases in bacterial production after $24 \mathrm{~h}$ of incubation could have been a consequence of a 'bottle effect', or weak top-down control of the bacteria during the study period. The latter effect seems unlikely, however, given the large differences between bacterial production values in the $<1 \mu \mathrm{m}$ and unfiltered seawater samples (2- to 3-fold on Georges Bank and >10fold in the Sargasso Sea).

Our results indicate that inorganic nutrients are a potentially limiting factor for bacterial growth, particularly in nutrient-poor environments. The results of 2 of our Georges Bank experiments typified the classical response of the bacterial community to enrichment with labile organic carbon (glucose). In contrast, the response of the bacterial assemblages in the Sargasso Sea experiments indicated primarily nitrogen and/or phosphorus limitation of bacterial growth. It is important to note, however, that there is likely to be considerable spatial and temporal variability within these broad generalities. Carlson \& Ducklow (1996), for example, found no evidence for the stimulation of bacterial production by the addition of inorganic nitrogen or phosphorus in a seasonal study working in the same vicinity as the Sargasso Sea station occupied in the present study. Only the addition of labile organic carbon substrate stimulated bacterial production in that study. These contradictory findings presumably indicate that nutritional conditions, and the specific factors limiting production by planktonic bacterial assemblages, can and do change rapidly in nature.

Acknowledgements. The authors gratefully acknowledge the help and support of the captain and crew of the RV 'Oceanus'. This work was supported by National Science Foundation grant OCE-8901005. Woods Hole Oceanographic Institution Contribution Number 10232.

\section{LITERATURE CITED}

Bratbak G, Thingstad TF (1985) Phytoplankton-bacteria interactions: an apparent paradox? Analysis of a model system with both competition and commensalism. Mar Ecol Prog Ser 25:23-30

Carlson CA, Ducklow HW (1996) Growth of bacterioplankton and consumption of dissolved organic carbon in the Sargasso Sea. Aquat Microb Ecol 10:69-85

Caron DA (1990) Evolving role of protozoa in aquatic nutrient cycles. In: Reid, PC, Turley, CM, Burkill, PH (eds) Protozoa and their role in marine processes, Vol. 25. Springer-Verlag, Berlin, p 387-415

Caron DA (1994) Inorganic nutrients, bacteria and the microbial loop. Microb Ecol 28:295-298

Caron DA, Dam HG, Kremer P, Lessard EJ, Madin LP, Malone TC, Napp JM, Peele ER, Roman MR, Youngbluth MJ (1995) The contribution of microorganisms to particulate carbon and nitrogen in surface waters of the Sargasso Sea near Bermuda. Deep-Sea Res 42:943-972

Caron DA, Peele ER, Lim EL, Dennett MR (1999) Picoplankton and nanoplankton and their trophic relationships in surface waters of the Sargasso Sea south of Bermuda. Limnol Oceanogr 44:259-272

Cavender-Bares KK, Mann EL, Chisholm SW, Ondrusek ME, Bidigare RR (1999) Differential response of equatorial Pacific phytoplankton to iron fertilization. Limnol Oceanogr 44:237-246

Chrzanowski TH, Sterner RW, Elser JJ (1995) Nutrient enrichment and nutrient regeneration stimulate bacterioplankton growth. Microb Ecol 29:221-230

Coffin RB, Connolly JP, Harris PS (1993) Availability of dissolved organic carbon to bacterioplankton examined by oxygen utilization. Mar Ecol Prog Ser 101:9-22

Cotner JB Jr, Wetzel RG (1992) Uptake of dissolved inorganic and organic phosphorus compounds by phytoplankton and bacterioplankton. Limnol Oceanogr 37:232-243

Cotner JB, Ammerman JW, Peele ER, Bentzen E (1997) Phosphorus-limited bacterioplankton growth in the Sargasso Sea. Aquat Microb Ecol 13:141-149 
Currie DJ, Kalff J (1984) A comparison of the abilities of freshwater algae and bacteria to acquire and retain phosphorus. Limnol Oceanogr 29:298-310

del Giorgio PA, Cole JJ (1998) Bacterial growth efficiency in natural aquatic systems. Annu Rev Ecol Syst 29:503-541

Elser, JJ, Stabler, LB, Hassett, RP (1995) Nutrient limitation of bacterial growth and rates of bacterivory in lakes and oceans: a comparative study. Aquat Microb Ecol 9: 105-110

Fuhrman JA, Azam F (1982) Thymidine incorporation as a measure of heterotrophic bacterioplankton production in marine surface waters: evaluation and field results. Mar Biol 66:109-120

Goldman JC, Dennett MR (1991) Ammonium regeneration and carbon utilization by marine bacteria grown on mixed substrates. Mar Biol 109:369-378

Goldman JC, McCarthy JJ, Peavey DG (1979) Growth rate influence on the chemical composition of phytoplankton in oceanic waters. Nature 279:210-215

Goldman JC, Caron DA, Dennett MR (1987) Regulation of gross growth efficiency and ammonium regeneration in bacteria by substrate $\mathrm{C}: \mathrm{N}$ ratio. Limnol Oceanogr 32: $1239-1252$

Hoch MP, Kirchman DL (1995) Ammonium uptake by heterotrophic bacteria in the Delaware estuary and adjacent coastal waters. Limnol Oceanogr 40:886-897

Jansson M, Blomqvist P, Jonsson A, Bergström AK (1996) Nutrient limitation of bacterioplankton, autotrophic and mixotrophic phytoplankton, and heterotrophic nanoflagellates in Lake Örträsket. Limnol Oceanogr 41: 1552-1559

Kirchman DL (1994) The uptake of inorganic nutrients by heterotrophic bacteria. Microb Ecol 28:255-271

Kroer N, Jørgensen NOG, Coffin RB (1994) Utilization of dissolved nitrogen by heterotrophic bacterioplankton: a comparison of three ecosystems. Appl Environ Microbiol 60: 4116-4123

Landry MR, Barber RT, Bidigare R, Chai F, Coale KH, Dam HG, Lewis MR, Lindley ST, McCarthy JJ, Roman MR, Stoecker DK, Verity PG, White JR (1997) Iron and grazing constraints on primary production in the central equatorial Pacific: an EqPac synthesis. Limnol Oceanogr 42:405-418

Le J, Wehr JD, Campbell L (1994) Uncoupling of bacterioplankton and phytoplankton production in fresh waters is affected by inorganic nutrient limitation. Appl Environ Microbiol 60:2086-2093

Li WKW, Dickie PM, Irwin BD, Wood AM (1992) Biomass of bacteria, cyanobacteria, prochlorophytes and photosynthetic eukaryotes in the Sargasso Sea. Deep-Sea Res 39: 501-519

Malone TC, Pike SE, Conley DJ (1992) Transient variations in

Editorial responsibility: Fereidoun Rassoulzadegan,

Villefranche-sur-Mer, France phytoplankton productivity at the JGOFS Bermuda time series station. Deep-Sea Res 40:903-924

Michaels AF, Knap AH (1996) Overview of the U.S. JGOFS Bermuda Atlantic Time-series Study and the Hydrostation S program. Deep-Sea Res 43:157-198

Nagata T (1986) Carbon and nitrogen content of natural planktonic bacteria. Appl Environ Microbiol 52:28-32

Olson RJ, Chisholm SW, Zettler ER, Altabet MA, Dusenberry JA (1990a) Spatial and temporal distributions of prochlorophyte picoplankton in the North Atlantic Ocean. Deep-Sea Res 37:1033-1051

Olson RJ, Chisholm SW, Zettler ER, Armbrust EV (1990b) Pigments, size and distribution of Synechococcus in the North Atlantic and Pacific Oceans. Limnol Oceanogr 35:45-58

Parsons TR, Maita Y, Lalli CM (1984) A manual of chemical and biological methods for seawater analysis. Pergamon Press, Oxford

Porter KG, Feig YS (1980) The use of DAPI for identifying and counting aquatic microflora. Limnol Oceanogr 25:943-948

Rivkin RB, Anderson MR (1997) Inorganic nutrient limitation of oceanic bacterioplankton. Limnol Oceanogr 42:730-740

Sanders RW, Berninger UG, Lim EL, Kemp PF, Caron DA (2000) Heterotrophic and mixotrophic nanoplankton predation on picoplankton in the Sargasso Sea and on Georges Bank. Mar Ecol Prog Ser 192:103-118

Schweitzer B, Simon M (1995) Growth limitation of planktonic bacteria in a large mesotrophic lake. Microb Ecol 30: 89-104

Shiah FK (1999) Diel cycles of heterotrophic bacterioplankton abundance and production in the ocean surface waters. Aquat Microb Ecol 17:239-246

Thingstad TF (1987) Utilization of N, P, and organic $\mathrm{C}$ by heterotrophic bacteria. I. Outline of a chemostat theory with a consistent concept of 'maintenance' metabolism. Mar Ecol Prog Ser 35:99-109

Thingstad TF, Zweifel UL, Rassoulzadegan F (1998) P limitation of heterotrophic bacteria and phytoplankton in the northwest Mediterranean. Limnol Oceanogr 43:88-94

Vadstein O (1998) Evaluation of competitive ability of two heterotrophic planktonic bacteria under phosphorus limitation. Aquat Microb Ecol 14:119-127

Vadstein O, Olsen Y (1989) Chemical composition and phosphate uptake kinetics of limnetic bacterial communities cultured in chemostats under phosphorus limitation. Limnol Oceanogr 34:939-946

Wiebe PH, Beardsley RC (1996) Physical-biological interactions on Georges Bank and its environs. Deep-Sea Res 43: 1437-1438

Zweifel UL, Norrman B, Hagström Å (1993) Consumption of dissolved organic carbon by marine bacteria and demand for inorganic nutrients. Mar Ecol Prog Ser 101:23-32

Submitted: September 14, 1999; Accepted: May 26, 2000 Proofs received from author(s): July 18, 2000 